\title{
Profil Keterampilan Berpikir Kreatif Fisika Peserta Didik SMK
}

\author{
Devi Meiarti \\ Program Studi Pendidikan Fisika, Pascasarjana, Universitas Negeri Semarang \\ Jalan Kelud Utara III Petompon, Gajahmungkur, Semarang 50237 \\ E-mail:vhii.mei@gmail.com
}

\begin{abstract}
Abstrak
Penelitian ini bertujuan untuk menganalisis profil keterampilan berpikir kreatif peserta didik SMK pada mata pelajaran fisika. Penelitian ini merupakan penelitian deskriptif kuantitatif dengan menggunakan metode tes. Populasi yang digunakan dalam penelitian ini adalah seluruh siswa kelas XII SMK Islam Nurul Hadi di Kabupaten Demak. Sampel yang digunakan adalah 30 peserta didik yang dipilih secara random sampling. Instrumen penelitian yang digunakan adalah tes open-ended dengan empat butir soal masing-masing mewakili indikator berpikir kreatif. Indikator yang digunakan merupakan indikator yang telah disusun oleh seorang ahli. Hasil penelitian keterampilan berpikir kreatif siswa dalam pelajaran fisika sebesar $56,67 \%$ dan termasuk dalam kategori sedang. Hal tersebut sebagaimana ditunjukkan pada indikator kemampuan berpikir kreatif fluency $61,11 \%$, flexibility dan originality $57,78 \%$, dan elaboration $50,00 \%$. Kesimpulan penelitian ini adalah keterampilan berpikir kreatif siswa secara keseluruhan belum dapat dikatakan terlatih dengan baik. Namun, untuk indikator fluency atau berpikir lancar telah terlatih dengan baik.
\end{abstract}

Kata kunci: keterampilan, berpikir kreatif, peserta didik.

\begin{abstract}
The aim of this research is to analyze the initial profile of creative thinking skills in Vocational School students on physics learning. This research was a quantitative descriptive research using test method. The population used in this study were all students of class XII at SMK Islam Nurul Hadi in Demak Regency. The sample used was 30 student's selected by random sampling. The instrument used is a open-ended test with four items each representing an indicator of creative thinking. The indicators used are indicators that had been developed by an expert. The result of students' creative thinking skills in physic subject showed $56,67 \%$ which was categorized as sufficient. It was shown from the creative thinking skills indicators that fluency $61,11 \%$, flexibility and originality $57,78 \%$, and elaboration $50,00 \%$. Overall, it could be concluded and said that the ability of student's creative thinking had not been properly trained. However, for fluency indicator were eventually considered well-trained.
\end{abstract}

Keywords: skills, creative thinking, students.

\section{PENDAHULUAN}

Keterampilan berpikir kreatif memiliki nilai strategis di abad ke-21 (Songkram et.al, 2015). Keterampilan berpikir kreatif didefinisikan sebagai keterampilan yang dibutuhkan pada hampir semua mata pelajaran (Heilman \& Korte, 2010). Berpikir kreatif adalah proses seseorang untuk menciptakan sesuatu yang baru yang terjadi melalui kemiripankemiripan sesuatu atau melalui pemikiran analogis dan bertujuan untuk merangsang keingintahuan dan meningkatkan kemampuan berpikir divergen (Hermawati et.al, 2016). Menurut Herlina \& Qurbaniah (2017) keterampilan berpikir kreatif adalah keterampilan kognitif untuk memunculkan dan mengembangkan gagasan baru, ide baru sebagai pengembangan dari ide yang telah lahir sebelumnya dan keterampilan untuk memecahkan masalah.

Keterampilan berpikir kreatif penting untuk diberdayakan di sekolah karena merupakan salah satu keterampilan agar mampu hidup fungsional dan bermakna (Trilling \& Fadel, 2009). Keterampilan berpikir kreatif dapat dipelajari dan diperoleh melalui 
pendidikan (Cachia et.al., 2010; Dyer et.al., 2011). Penelitian ini dilakukan di SMK sejalan dengan hasil penelitian Hakan \& Mehmet (2015) bahwa keterampilan berpikir kreatif adalah yang paling penting yang harus dimiliki siswa terlebih lagi siswa SMK yang dituntut untuk selalu mengembangkan kreativitasnya dalam berkarya.

Pemikiran kreatif dan kreativitas menjadi salah satu keterampilan penting yang harus diperoleh untuk beradaptasi dengan perubahan globalisasi yang cepat (Gencer \& Gonen, 2015). Kreatif atau tidaknya seseorang berkaitan dengan lingkungan tempatnya berada. Lingkungan dapat mempengaruhi kemampuan kreatif seseorang dalam berinovasi serta berpikir. Kenyataannya keahlian dalam berpikir kreatif seseorang dapat dilatih melalui pembelajaran sejak dini (OECD, 2016). Ciri kognitif dalam berpikir kreatif, yaitu kelancaran, keluwesan, orisinalitas, dan elaborasi. Sedangkan ciri non kognitif dalam berpikir kreatif, yaitu motivasi, sikap dan kepribadian kreatif. Penelitian ini menggunakan tes berpikir kreatif dengan empat aspek tersebut untuk mengetahui cara peserta didik dalam memecahkan masalah fisika berdasarkan kelima aspek keterampilan berpikir kreatif (Munandar, 2012).

Beberapa hasil penelitian menunjukkan bahwa kemampuan berpikir kreatif peserta didik di Indonesia masih kurang. Djupanda et.al (2016) menyimpulkan peserta didik yang memiliki keterampilan berpikir aspek elaborasi mampu memecahkan masalah fisika lebih baik daripada peserta didik yang memiliki keterampilan berpikir kreatif pada aspek keluwesan, orisinalitas, dan kelancaran. Widiastuti \& Putri (2018) menyimpulkan kemampuan berpikir peserta didik tergolong cukup karena dalam menyelesaikan soal tes beberapa peserta didik masih ragu-ragu dalam memberikan penyelesaiannya. Sujarwo \& Yunianta (2018) menyimpulkan kemampuan berpikir kreatif terlihat berbeda pada peserta didik berkemampuan matematika tinggi, sehingga akan lebih baik jika latihan soal yang diberikan merupakan open-ended. Penelitian Fadilah dalam Sulistiarmi et.al (2016) menyatakan bahwa beberapa pengajar memiliki kesulitan dalam mengetahui kemampuan berpikir kreatif peserta didik. Hal ini karena banyak peserta didik yang takut mencoba, takut melakukan hal baru, dan mengeluarkan bakatnya. Menurut Yunianta (2014) salah satu faktor yang menghambat peserta didik untuk berpikir kreatif adalah kebiasaan.

\section{METODE}

Penelitian ini merupakan penelitian deskriptif kuantitatif dengan menggunakan metode tes. Populasi dari penelitian ini adalah peserta didik SMK Islam Nurul Hadi di Kabupaten Demak. Sampel yang digunakan adalah 30 peserta didik yang dipilih secara random sampling. Data tes diperoleh dengan cara menyebarkan instrument untuk 30 peserta didik. Instrumen penelitian yang digunakan adalah tes open-ended dengan empat butir soal masing-masing mewakili indikator berpikir kreatif. Selanjutnya persentase untuk masingmasing indikator dihitung menggunakan persamaan (1) sebagai berikut:

$$
S=\frac{R}{N} \times 100
$$

Keterangan :

$S=$ Skor kemampuan berpikir kreatif

$\mathrm{R}=$ skor benar

$\mathrm{N}=$ skor maksimal

Kesimpulan profil kemampuan peserta didik dalam berpikir kreatif diperoleh dengan membandingkan persentase yang telah diperoleh dengan Tabel 1.

Tabel 1. Kriteria kemampuan berpikir kreatif

\begin{tabular}{cc}
\hline Dalam Persen $(\%)$ & Kriteria \\
\hline $81,00-100,00$ & Sangat Baik \\
$61,00-80,00$ & Baik \\
$41,00-60,00$ & Cukup \\
$21,00-40,00$ & Kurang \\
$0,00-20,00$ & Sangat Kurang \\
\hline \multicolumn{2}{c}{ Sumber: Sugiyanto et.al (2018) }
\end{tabular}

Peneitian ini menggunakan indikator keterampilan berpikir kreatif sebagaimana yang termasuk dalam ciri kognitif keterampilan berpikir kreatif oleh Munandar (2012) yaitu 
kelancaran (fluency), keluwesan (flexibility), orisinil (originality), dan elaborasi (elaboration).

HASIL DAN PEMBAHASAN

\section{HASIL}

Hasil analisis tes keterampilan berpikir kreatif peserta didik di SMK Islam Nurul Hadi ditunjukkan pada Tabel 2.

Tabel 2. Hasil analisis tes keterampilan berpikir kreatif

\begin{tabular}{lccccc}
\hline Indikator & Persentase & Kriteria & $\begin{array}{c}\text { Skor } \\
\text { Tertinggi }\end{array}$ & $\begin{array}{c}\text { Skor } \\
\text { Menengah }\end{array}$ & $\begin{array}{c}\text { Skor } \\
\text { Terendah }\end{array}$ \\
\hline Fluency & $61,11 \%$ & Baik & 5 orang & 15 orang & 10 orang \\
Flexibility & $57,78 \%$ & Cukup & 8 orang & 6 orang & 16 orang \\
Originality & $57,78 \%$ & Cukup & 9 orang & 4 orang & 17 orang \\
Elaboration & $50,00 \%$ & Cukup & 2 orang & 11 orang & 17 orang \\
\hline Rata-rata & $56.67 \%$ & & & Cukup & \\
\hline
\end{tabular}

Data hasil penelitian berdasarkan Tabel 2 keterampilan berpikir kreatif peserta didik SMK Islam Nurul Hadi dalam pelajaran fisika sebesar $56,67 \%$ dan termasuk dalam kategori cukup. Hal tersebut sebagaimana di tunjukkan pada indikator keterampilan berpikir kreatif fluency (berpikir lancar) sebesar 61,11\%, flexibility (berpikir luwes) dan originality (berpikir orisinil) sebesar 57,78\%, serta elaboration (berpikir memerinci) sebesar $50,00 \%$.

\section{PEMBAHASAN}

Penelitian ini bertujuan menganalisis profil awal keterampilan berpikir kreatif peserta didik SMK pada mata pelajaran fisika. Berpikir kreatif didefinisikan sebagai proses pemikiran yang memungkinkan peserta didik untuk menerapkan imajinasi mereka untuk menghasilkan ide dan menggunakan ide-ide kreatif untuk memberikan solusi (Kamplys \& Berki, 2014; Wahsheh, 2017). Profil keterampilan berpikir kreatif peserta didik direpresentasikan oleh empat indikator. Indikator pertama yakni fluency (berpikir lancar) merepresentasikan kemampuan untuk menghasilkan banyak gagasan dalam waktu singkat. Indikator kedua yakni flexibility atau berpikir luwes merepresentasikan kemampuan untuk mengemukakan bermacam-macam pemecahan atau pendekatan terhadap masalah. Indikator ketiga yakni originality atau berpikir orisinil merepresentasikan kemampuan untuk mencetuskan gagasan dengan cara-cara yang asli, tidak klise dan berbeda dari orang lain. Indikator keempat yakni elaboration atau memerinci merepresentasikan kemampuan menahan situasi atau masalah sehingga menjadi lengkap dan merincinya secara detail.

Penelitian ini menggunakan soal openended untuk mengukur profil berpikir kreatif peserta didik. Pertanyaan harus disajikan kepada peserta didik untuk membuat mereka berbicara tentang ide-ide unik yang melibatkan imajinasi dan kreativitas mereka (Simsek \& Kiyici, 2010). Data penelitian diperoleh berdasarkan jawaban dari soal yang masingmasing nomor merepresentasikan indikator berpikir kreatif. Soal instrumen terkait dengan materi fisika yaitu suhu dan kalor. Pengerjaan instrumen tes dibatasi waktu yaitu selama 40 menit.

Hasil penelitian menunjukkan bahwa keterampilan berpikir kreatif peserta didik belum terlatih dengan baik. Temuan ini memiliki kesesuaian dengan beberapa hasil penelitian sebelumnya yang juga menunjukkan bahwa keterampilan berpikir kreatif di Indonesia masih rendah. Tingkat rendah pemikiran kreatif terbukti dalam beberapa penelitian pada skala nasional (Syafi'l et.al, 2011; Suparman \& Husen, 2015; Yuliani et.al, 2017). Kurangnya pemikiran kreatif tidak hanya terjadi dalam skala nasional, tetapi juga terjadi di Arab (Wahseh, 2017). Beberapa faktor dapat mempengaruhi perkembangan kreativitas antara lain yakni kecerdasan, pengetahuan, motivasi, lingkungan sosial, konteks budaya, dan kepribadian (Cheng-Ping, 2013).

Keterampilan berpikir kreatif pada indikator pertama yakni fluency (berpikir lancar) diperoleh persentase sebesar $61,11 \%$. Hasil tersebut merupakan indikator dengan perolehan tertinggi dan termasuk dalam kriteria 
baik. Terdapat 5 orang peserta didik atau $16,67 \%$ yang memperoleh skor tertinggi dan 10 orang peserta didik atau $33,33 \%$ memperoleh skor terendah. Tingkat kesukaran soal termasuk dalam kriteria sedang. Soal meminta peserta didik untuk menjelaskan pemuaian air raksa pada termometer.

Keterampilan berpikir kreatif pada indikator kedua yakni flexibility (berpikir luwes) diperoleh persentase sebesar $57,78 \%$. Hasil tersebut termasuk dalam kriteria cukup. Terdapat 8 orang peserta didik atau $26,67 \%$ yang memperoleh skor tertinggi dan 16 orang peserta didik atau $53.33 \%$ memperoleh skor terendah. Tingkat kesukaran soal termasuk dalam kriteria sedang. Soal meminta peserta didik untuk menganalisis peristiwa anomali air.

Keterampilan berpikir kreatif pada indikator ketiga yakni originality (berpikir orisinal) diperoleh persentase sebesar $57,78 \%$. Hasil tersebut termasuk dalam kriteria cukup. Terdapat 9 orang peserta didik atau 30,00\% yang memperoleh skor tertinggi dan 17 orang peserta didik atau $56.67 \%$ memperoleh skor terendah. Tingkat kesukaran soal termasuk dalam kriteria sedang. Soal meminta peserta didik untuk membandingkan kalor jenis antara dua bahan.

Keterampilan berpikir kreatif pada indikator keempat yakni elaboration (berpikir rinci) diperoleh persentase sebesar $50,00 \%$. Hasil tersebut merupakan indikator dengan perolehan terendah dan termasuk dalam kriteria cukup. Terdapat 2 orang peserta didik atau $6,67 \%$ yang memperoleh skor tertinggi dan 17 orang peserta didik atau 56.67\% memperoleh skor terendah. Tingkat kesukaran soal termasuk dalam kriteria sedang. Soal meminta peserta didik untuk menjelaskan kapasitas kalor dalam kehidupan sehari-hari.

Penilaian keterampilan berpikir kreatif berdasarkan indikator Guilford (Sugiyanto et.al, 2018) menunjukkan bahwa beberapa peserta didik hampir mencapai target dalam indikator fluency. Sedangkan untuk tiga indikator lain yaitu flexibility, originality, dan elaboration belum banyak yang mencapai target. Hal ini menunjukkan bahwa keterampilan berpikir kreatif peserta didik tidak dilatih secara optimal. Oleh karena itu, penting untuk menggunakan keterampilan ini dalam pembelajaran, terutama pada pembelajaran fisika. Berbagai penelitian telah menganalisis persepsi guru tentang keterampilan kreatif; hasil umumnya menunjukkan bahwa guru sadar akan dampak positif dari pembelajaran dan kehidupan seharihari dari kreativitas (Pizzingrili et.al, 2014). Pelatihan yang efektif untuk berkontribusi pemikiran kreatif biasanya berfokus pada strategi yang terkait dengan definisi masalah, konseptual, ide, dan perencanaan implementasi (Mumford et.al, 2012).

\section{PENUTUP}

Profil awal keterampilan berpikir kreatif peserta didik dalam pembelajaran fisika termasuk dalam kriteria cukup, dengan kualifikasi indikator fluency atau berpikir lancar sebagai indikator dengan persentase tertinggi serta indikator elaboration atau berpikir rinci sebagai indikator dengan persentase terendah. Kesimpulan penelitian ini adalah keterampilan berpikir kreatif siswa secara keseluruhan belum dapat dikatakan terlatih dengan baik. Namun, untuk indikator fluency atau berpikir lancar telah terlatih dengan baik. Mengetahui profil awal keterampilan berpikir kreatif peserta didik masih dalam kriteria cukup, maka perlu dibutuhkan pendukung pembelajaran guna meningkatkan keterampilan berpikir kreatif.

\section{UCAPAN TERIMAKASIH}

Puji dan syukur kehadirat Allah SWT karena atas aliran rahmat dan kasih-Nya yang tiada henti sehingga penelitian ini dapat terselesaikan dengan baik. Terima kasih kepada SMK Islam Nurul Hadi yang telah bersedia menerima untuk melaksanakan penelitian di sekolah. Terima kasih juga kepada seluruh pihak yang telah membantu dalam penelitian ini.

\section{REFERENSI}


Cachia, R., Ferrari, A., Ala-Mutka, K \& Punie, Yves. (2010). "Creative Learning and Innovative Teaching: Final Report on the Study on Creativity and Innovation in Education in the EU Member State". Journal Joint Research Center Insitute for Prospective Technological Studies, (Online), JRC European Commission, (http://ftp.jrc.es/EURdoc/JRC62370.pdf, diakses 14 Oktober 2018).

Cheng-Ping, C. (2013). "Relationships between Playfulness and Creativity among Students Gifted in Mathematics and Science". Creative Education, 4 (2), 101-109.

Djupanda, H., Kendek, Y \& Darmadi, I. W. (2016). "Analisis Keterampilan Berpikir Kreatif Peserta didik SMA dalam Memecahkan Masalah Fisika". Jurnal Pendidikan Fisika Tadulako (JPFT), 3 (2), 29-34.

Dyer, J., Christensen, Clay \& Gregersen, Hal. (2011). The Innovator's DNA: Mastering the Five Skills of Disruptive Innovators. Havard Bussines Review. (Online), (http://hbr.org, diakses 14 Oktober 2018).

Gencer, A. A \& Gonen, M. (2015). "Examination of The Effects of Reggio Emilia Based Projects on Preschool Children's Creative Thinking Skills". Procedia-Social and Behavioral Sciences, 186, 456 - 460.

Hakan, T \& Mehmet, S. (2015). "Creative Thinking Skills Analyzes Of Vocational High School Students". Journal of Educational and Instructional Studies in The World, 5 (10), 74-84.

Heilman, G \& Korte, W. B. (2010). The Role of Creativity and Innovation in School Curricula in the EU27 (Luxembourg: Publicatios Office of the European Union).

Herlina, L \& Qurbaniah, M. (2017). "Analisis Kemampuan Berpikir Kreatif Peserta didik Pada Materi Virus Kelas X MAS AlMustaqim Sungai Raya 2". Jurnal Bioeducation, 2 (1), 11-14.

Hermawati, R., Haeruddin \& Darmadi, I. W. (2016). "Analisis Keterampilan Berpikir Kreatif Peserta didik Kelas $X$ dalam Pokok Bahasan Dinamika Partikel". Jurnal Pendidikan Fisika Tadulako (JPFT), 2 (4), 15-18.
Kamplys \& Berki. (2014). Nurturing Creative Thinking. UNESCO. (Online), http://unesdoc.unesco.org/images/0022/00 2276/227680e.pdf, diakses 26 November 2018.

Mumford, M. D., Medeiros, K. E \& Partlow, $P$. J. (2012). "Creative thinking: Processes, strategies, and knowledge". Journal of Creative Behavior, $46,30-47$.

Munandar, U. (2012). Pengembangan Kreativitas Anak Berbakat. Jakarta: Rineka Cipta.

OECD. (2016). PISA 2015 Result (Volume 1): Excellent and Equity in Education. Paris: OECD Publishing.

Pizzingrili, P., Valenti, C., Cerioli, L \& Antonietti, A. (2014). "Creative Thinking Skills From 6 To 17 Years As Assessed Through The WCR Test". Procedia-Social and Behavioral Sciences, 191, $584-590$

Simsek, C. L \& Kiyici, F. B. (2010). "How much science and technology lesson student studying books support creative thinking?" Procedia-Social and Behavioral Sciences, 2(2), 2105-2110.

Songkram, N. (2015). "E-learning System in Virtual Learning Environment to Develop Creative Thinking for Learners in Higher Education," Procedia-Social and Behavioral Sciences, 174, 674-679.

Sugiyanto, F. N., Masykuri, M \& Muzzazinah. (2018). "Analysis of senior high school students' creative thinking skills profile in Klaten regency". IOP Conf. Series: Journal of Physics: Conf. Series, 1006.

Sujarwo, E \& Yunianta, T. N. H. (2018). "Analisis Kemampuan Berpikir Kreatif Peserta didik Kelas VIII SMP dalam Menyelesaikan Soal Luas Bangun". Jurnal Kajian Pembelajaran Matematika, 2 (1), 01-09.

Sulistiarmi, W., Wiyanto \& Nugroho, S. E. (2016). "Analisis Kemampuan Berpikir Kreatif Peserta didik Kelas XI-IPA pada Mata Pelajaran Fisika SMA Negeri Se-Kota Pati". Unnes Physics Education Journal, 5 (2), 95101.

Suparman., \& Husen, D. N. (2015). "Peningkatan Kemampuan Berpikir Kreatif Peserta didik 
Melalui Penerapan Model Problem Based Learning". Bioedukasi, 3 (2), 367-372.

Syafi'l, W., Suryawati, E \& Saputra, A. R. (2011). "Kemampuan Berpikir Kreatif dan Penguasaan Konsep Peserta didik Melalui Model Problem Based Learning (PBL) dalam Pembelajaran Biologi Kelas XI IPA SMAN 2 Pekanbaru Tahun Ajaran 2010/2011". Biogenesis (Jurnal Pendidikan Sains Dan Biologi), 8 (1), 1-7.

Trilling, B \& Fadel, C. (2009). 21st Century Skills: Learning for Life in Our Times. New York: Jossey-Bass.

Wahsheh, R. A. (2017). "Difficulties of Applying Creative Thinking Skills in Teaching from the Perspective of Faculty Members in Najran University, Saudi Arabia". American Journal of Educational Research, Vol. 5, No. 4, 409-418.

Widiastuti, Y \& Putri, R. I. I. (2018). "Kemampuan Berpikir Kreatif Peserta didik pada Pembelajaran Operasi Pecahan Menggunakan Pendekatan Open-Ended". Jurnal Pendidikan Matematika, 12 (2), 1322.

Yuliani, H., Mariati., Yulianti, R \& Herianto, C. 2017. "Keterampilan Berpikir Kreatif pada Siswa Sekolah Menengah di Palangka Raya Menggunakan Pendekatan Saintifik". Jurnal Pendidikan Fisika dan Keilmuan (JPFK), vol.3, no.1, pp. 48-56.

Yunianta, T. N. H. (2014). "Hambatan Seseorang Mengembangkan Kemampuan Berpikir Kreatif Matematis". Jurnal IImiah Pendidikan, Sejarah, dan Sosial Budaya Widya Sari, 16 (2), 48-60. 